Article

\title{
Food Security in Romania-A Modern Approach for Developing Sustainable Agriculture
}

\author{
Nicolae Istudor $^{\dagger}$, Raluca Andreea Ion ${ }^{\dagger, *}$, Maria Sponte ${ }^{\dagger}$ and Irina Elena Petrescu ${ }^{\dagger}$ \\ Department of Agro-food and Environmental Economy, The Bucharest University of Economic \\ Studies, 6 Piata Romana, Bucharest 010374, Romania; E-Mails: nicolae.istudor@ase.ro (N.I.); \\ maria.sponte@yahoo.com (M.S.); irina.petrescu@eam.ase.ro (I.E.R.) \\ $\dagger$ These authors contributed equally to this work. \\ * Author to whom correspondence should be addressed; E-Mail: raluca.ion@eam.ase.ro; \\ Tel.: +40-722-959-353.
}

External Editor: Marc. A. Rosen

Received: 26 September 2014; in revised form: 20 October 2014 / Accepted: 25 November 2014 / Published: 2 December 2014

\begin{abstract}
This paper investigates the state of food security in Romania and its place in the world. We analysed the level of food security indicators for 1990-2012, in Romania, and their average levels worldwide. References are also made to developed and developing countries. The research seeks to answer the questions: Is food security achieved in Romania and, if so, what kind of structural changes can be made towards improving food quality and people's living standards? As indicators show, the findings indicate that food security is ensured, on average, in Romania. Dietary energy supply is above dietary energy requirements, the ratio of cereals import dependency is below its average level worldwide, and the daily diet is balanced between vegetal and animal origin food. Having solved the quantitative aspect of food security, Romania can look towards improving the qualitative aspects of it. In this regard, organic food may be considered as a direction of developing sustainable agricultural economy.
\end{abstract}

Keywords: food security; dietary energy supply; organic farming; organic food; sustainable agriculture 


\section{Introduction}

Debate about food security has intensified in recent times. There are many definitions of the term, implying nutritional, economical and social dimensions. The Food and Agricultural Organisation (FAO) of the United Nations considers that "food security exists when all people, at all times, have physical, social and economic access to sufficient, safe and nutritious food which meets their dietary needs and food preferences for an active and healthy life" (FAO website [1], 2014).

Food security is analyzed periodically by FAO. The last reports indicate that about one in every nine people in the world still has insufficient food for an active and healthy life. "The vast majority of these undernourished people live in developing countries, where an estimated 791 million were chronically hungry in 2012-2014", FAO [2] (p. 8). Still, "since 1990-1992, the prevalence of under-nourishment has fallen from $18.7 \%$ to $11.3 \%$ in $2012-14$ for the world as a whole, and from $23.4 \%$ to $13.5 \%$ for developing regions", FAO [2] (p. 4).

In 1996, the United Nations General Assembly expressed at the World Food Summit the global Millennium Development Goals of reducing by half the proportion of undernourished people until the end of 2015 [3]. This target is within reach, if appropriate and immediate efforts are stepped up. FAO estimates that the target has already been achieved by many countries: "sixty-three developing countries have already reached the target, 11 of which have maintained the prevalence of under-nourishment below 5\% since 1990-1992, while another six are on track to do so by 2015 . Twenty-five of the 63 countries have also accomplished the more ambitious 1996 World Food Summit goal of halving the number of chronically underfed people", FAO [2] (p. 4).

The International Food Policy Research Institute developed a 2020 Vision of a world "where every person has economic and physical access to sufficient food to sustain a healthy and productive life, where malnutrition is absent, and where food originates from efficient, effective, and low-cost food and agricultural systems that are compatible with sustainable use and management of natural resources", IFPRI [4] (p. 9). Pinstrup-Andersen and Pandya-Lorch [5] (p. 1) believe that "the 2020 Vision of food security and sustainable use of natural resources will be reached if all relevant parties-individuals, households, farmers, local communities, civil society, private sector, national governments, and the international community - take appropriate actions and change their behaviour, priorities, and policies". Such actions refer to investing more in poor people, accelerating agricultural productivity, assuring sound management of natural resources, strengthening the capacity of developing-country governments to perform appropriate functions, and expanding and realigning international development assistance. Furthermore, Pinstrup-Andersen and Pandya-Lorch [5] (p. 2) argue that "the world's natural resources are capable of supporting the 2020 Vision, if current rates of degradation are reduced and replaced by appropriate technological change and sustainable use of natural resources".

Many other works have discussed and analyzed the phenomenon of food security, its implications and factors. Cassman and Harwood [6] (p. 439) investigated the nature of agricultural systems and relationships with food security and environmental balance. They conclude that "global food security in the future will depend on growth in production in those areas of the world with favourable soils, adequate water resources, and high yields from wheat and rice cropping". Parry et al. [7] investigate food security in relation to climate change. They conclude that climate change, due to increasing 
greenhouse gases, is likely to affect crop yields differently from region to region across the globe. Climate change is likely to benefit crop yields in mid to high latitudes, but to be detrimental in low-latitude regions.

Hanjra and Qureshi [8] (p. 365) examined linkages between water supply and food security. Their analysis reveals that "the water for food security situation is intricate and might get daunting if no action is taken". Droogers [9] (p. 15) found out that "the overall impact of climate change on food security and environmental quality appears to be positive as a result of enhanced crop growth due to higher $\mathrm{CO}_{2}$ levels and a small increase in precipitation". Similar results were obtained by Akenji and Bengtsson [10], Kang et al. [11], Sage [12], Devereux and Edwards [13], Eakin [14], and Ericksen [15], who studied the issue of food security and its implications to sustainable development.

Timmer concludes that "rather than asking how to cope with hunger and famine, the question might be how to escape their threat altogether" [16] (p. 283). The solution could consist in recognizing that agriculture and the rural economy are greatly influenced by policies and outcomes in the rest of the economy. Strategies may include economic growth with unchanging income distribution, and growth with redistribution (Constance, 2010) [17]. The latter encourages balanced growth to create non-farm employment opportunities, while investing in rural infrastructure.

These are, more or less, issues that are also relevant for Romania. Previous research as Botezatu and Andrei [18], Ion and Popescu [19], Done et al. [20] or Bazga [21] (p. 1264) shows that, for over four decades, Romania has made remarkable progress in food production and food security. However, food security progress is rather slow and depends largely on social and political conditions at some point.

Reports of the Economist Intelligence Unit [22] (pp. 9,10) assess the global food security index in 2012, considering food affordability, availability and quality. Countries are ranked on a scale from 0 to 100. Romania ranks 38th, with a score of 62.5 (China ranks on the same place). As regards to affordability, Romania ranked 11th, in upper middle income class (US\$ 3976-12,275 per capita). In 2014, the overall score fell for Romania compared with two years before: 61.3. In 2014, Romania ranks 44th. As regards rankings by regional classification, the place of Romania within European countries is the 23rd out of 26 (Economist Intelligence Unit [23] (pp. 13,16).

This article seeks to investigate the state of food security in Romania in the view of the FAO food security indicators. The overarching research question that this article tries to answer is: Is food security achieved in Romania and, if so, what kind of structural changes can be made towards improving food quality and people's life standards? Related research questions are: What is the place of Romania compared to the average worldwide regarding food security assurance? Is Romania dependent on cereals import? Do Romanians have a balanced diet between vegetal and animal origin food? In pursuing the answer to these questions, statistical data from FAOSTAT have been gathered and analysed in the experimental section. The objectives of this paper are to identify the state of food security in Romania and its potential to develop organic farming as a direction for improving food quality and living standards.

\section{Experimental Section}

In this section, the state of food security in Romania is estimated. Food security of a country is assessed using a set of indicators elaborated by the FAO. It includes thirty-one items, grouped in four 
categories: availability; access; stability and utilization. For estimating food security in Romania, some items are analyzed, and some are excluded. Excluded items refer to aspects such as under-nourishment, percentage of adults/children who are underweight, political instability and violence/terrorism, etc., which is not the case of Romania. Some indicators are more general and refer to the percentage of paved roads over total roads, road/rail lines density, and access to improved water sources. These factors are not subject to this piece of research that tries to analyze whether Romania has enough agricultural potential to ensure food security.

In accordance to the reasons above, the main indicators that enable making a picture of how food security is achieved in Romania, compared to world average, are: average dietary energy supply adequacy, dietary energy supply, average value of food production, share of dietary energy supply derived from cereals, roots and tubers, average protein supply, average supply of proteins of animal origin, and cereal import dependency ratio. In addition, GDP per capita is analyzed, to have an overview of Romania's place among other nations and to make correlations to the average value of food production.

GDP per capita based on purchasing power parity is gross domestic product converted to international dollars using purchasing power parity rates. An international dollar has the same purchasing power over GDP as the US dollar has in the United States. Data in Figure 1 are in constant 2011 international dollars. They show an upward trend of GDP per capita since 1990 to the present. Romania has a GDP of 17,941 I\$ per capita, higher than the world average of 13,972 I\$. In the World Bank classifications, Romania ranks 11 th out of 27 countries in upper middle income class (Economist Intelligence Unit [22] (p. 15).

Figure 1. Gross domestic product per capita, in purchasing power equivalent (constant 2011 international \$).

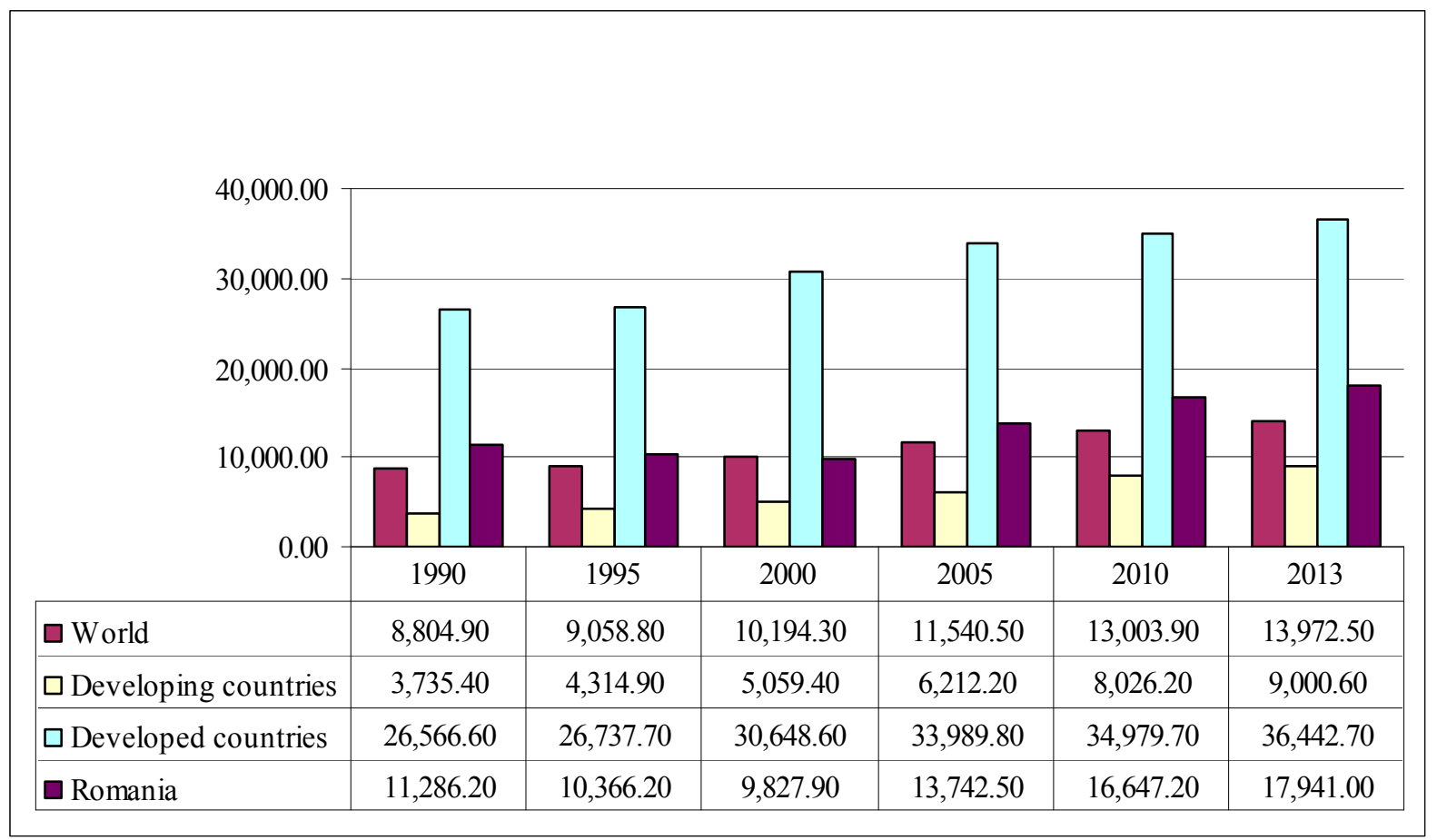

Source: Authors' calculation based on FAOSTAT data [24]. 
Data in Figure 2 express the Dietary Energy Supply as a percentage of the Average Dietary Energy Requirements in each country. Each country's or region's average supply of calories for food consumption is normalized by the average dietary energy requirement estimated for its population, to provide an index of adequacy of the food supply in terms of calories. It can be noticed that in Romania, worldwide, in developed and developing countries, the dietary energy supply is above the average dietary energy requirements. Dietary energy supply in Romania exceeds the requirements with $36 \%$.

Figure 2. Average Dietary energy supply adequacy (\%).

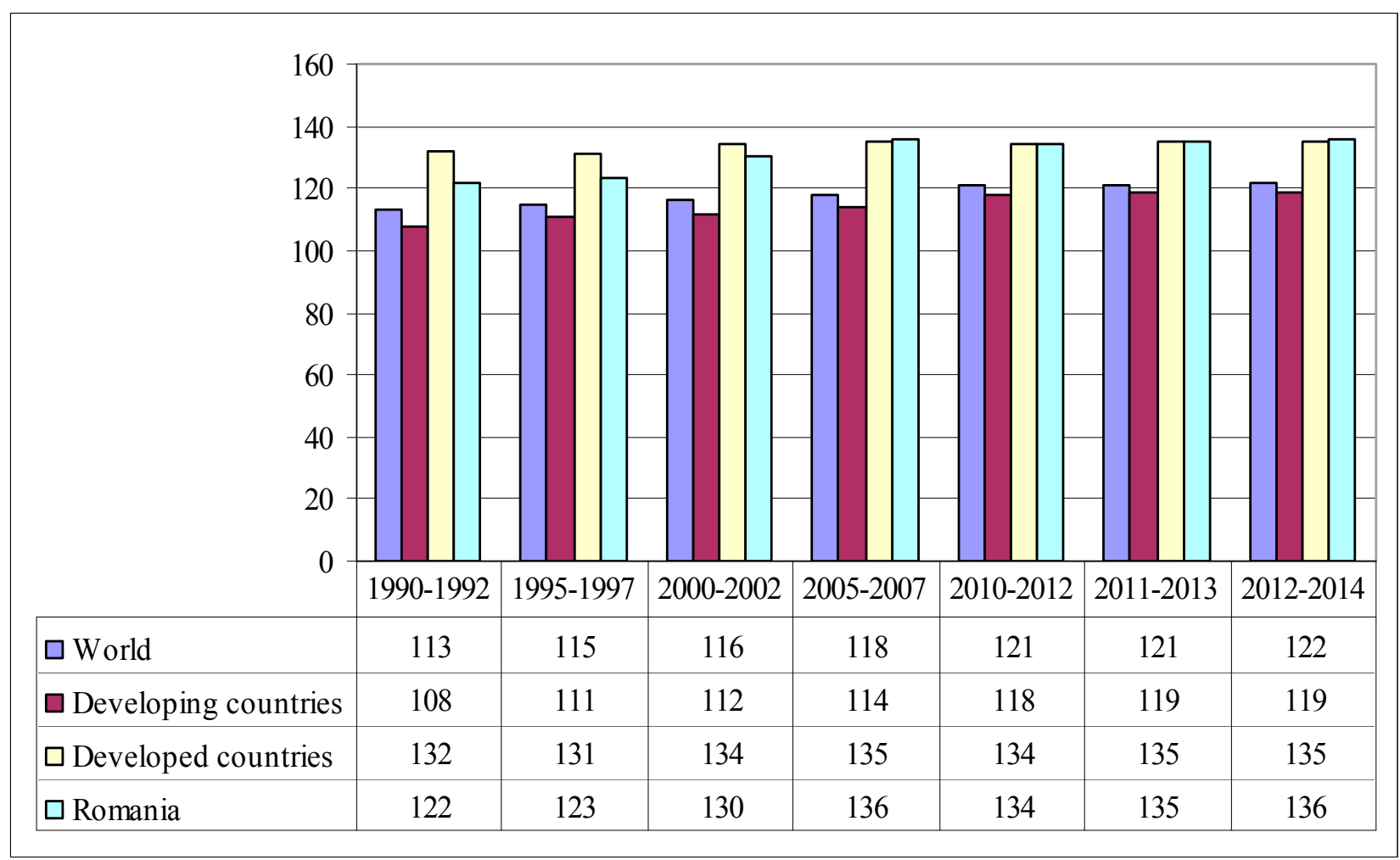

Source: Authors' calculation based on FAOSTAT data [24].

In Figure 3, the human food consumption expressed in kilocalories per person per day shows that, in Romania, dietary energy supply is 3363 , higher than world average of 2881, and close to its level in developed countries of $3399 \mathrm{kcal} /$ person/day. For both groups of countries: developed and developing, and for Romania and worldwide, the dietary energy supply increased since 1990 to present, and stabilized around $2769 \mathrm{kcal} / \mathrm{person} /$ day in developing countries and to $3399 \mathrm{kcal} / \mathrm{person} / \mathrm{day}$ in developed countries.

Data in Figure 4 show the energy supply (in kcal/caput/day) provided by cereals, roots and tubers divided by total dietary energy supply, presented in Figure 3. Low shares indicate that food intake is based on vegetal origin products that provide low levels of energy and a diet based mostly on carbohydrates and less on protein. As shown in Figure 4, in developing countries, the share of cereals, roots and tubers is $56 \%$, higher than its level in developed countries $(32 \%)$, indicating a diet based on vegetal origin food in the first group of countries. In Romania, the share of cereals, roots and tubers in total dietary energy supply is $45 \%$, indicating a balance between vegetal and animal origin food. 
Figure 3. Dietary energy supply (kcal/caput/day).

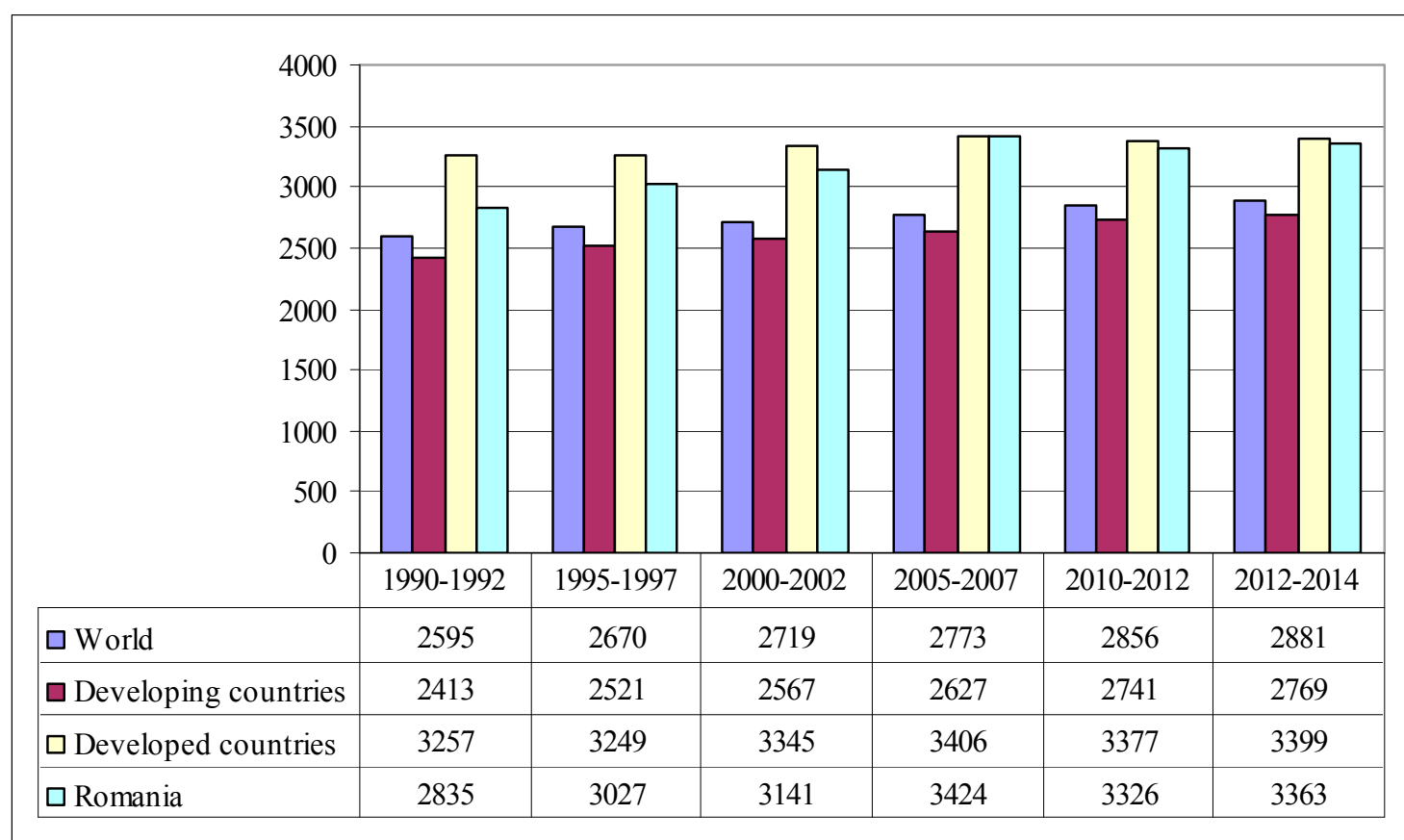

Source: Authors' calculation based on FAOSTAT data [24].

Figure 4. Share of dietary energy derived from cereals, roots and tubers (\%).

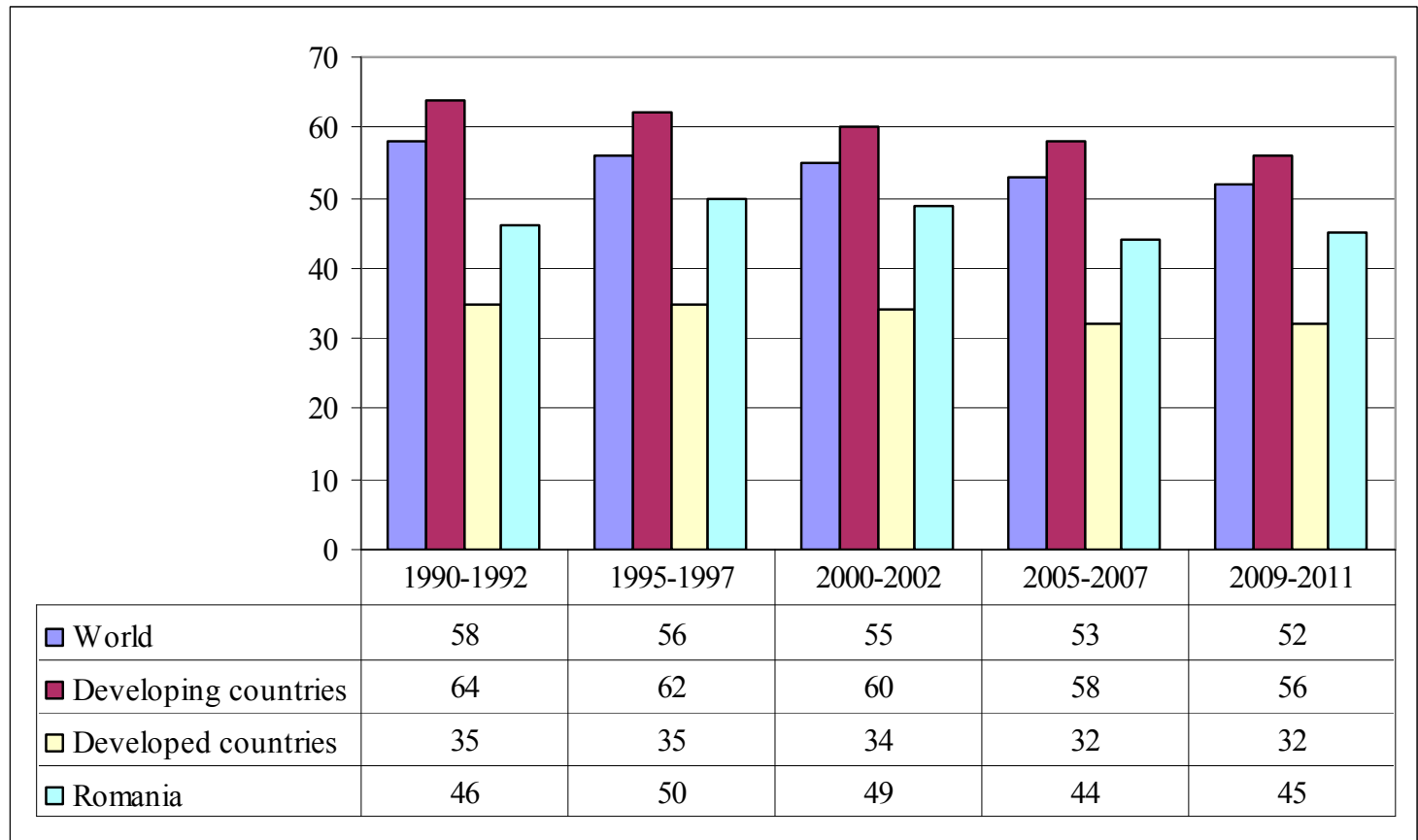

Source: Authors' calculation based on FAOSTAT data [24].

In developed countries, people consume 103 grams of protein per day, compared to 74 grams in developing countries (Figure 5). Worldwide, people consume 79 grams of protein per day. In Romania, consumption of protein is even higher than in developed countries: 106 grams per day. Consumption of protein shows an upward trend, worldwide, even in developing countries, showing that food security improved, in a qualitative approach. 
Figure 5. Average protein supply (gram/caput/day).

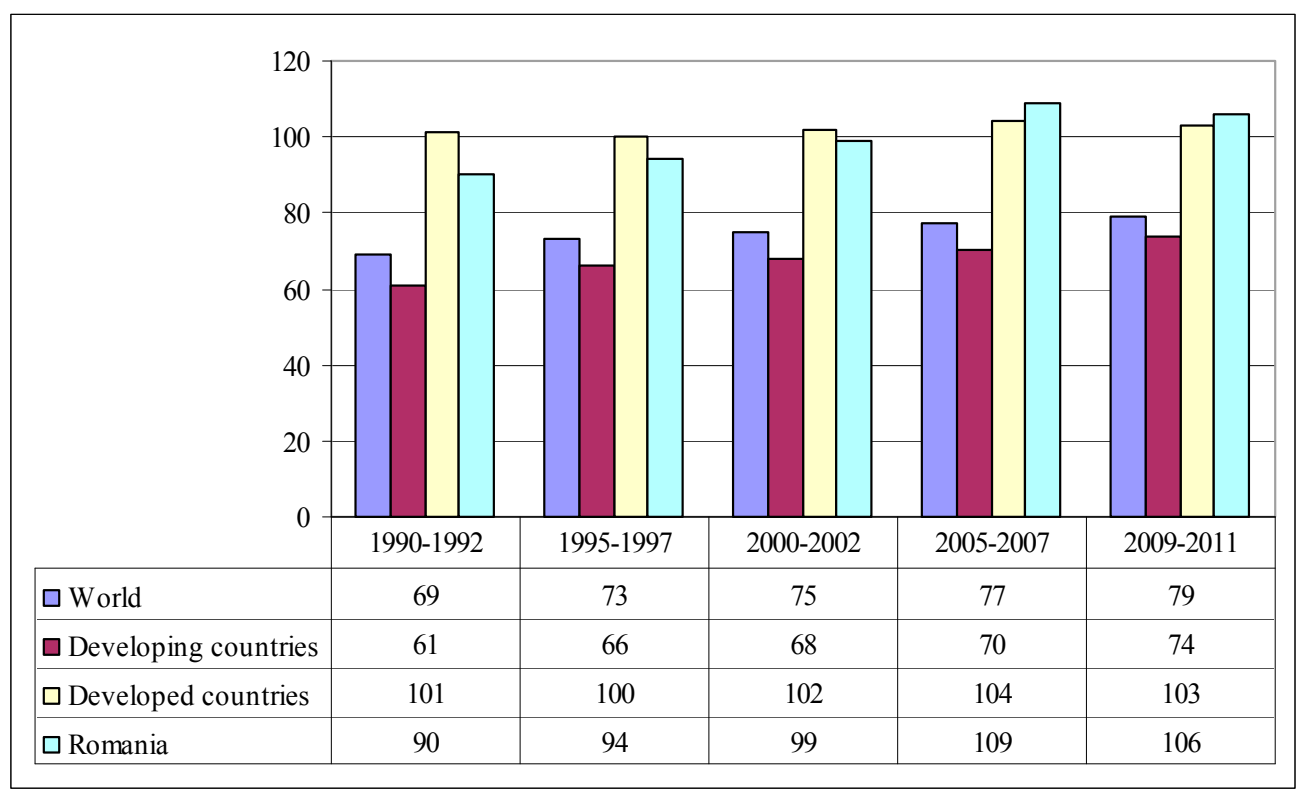

Source: Authors' calculation based on FAOSTAT data [24].

The average supply of protein of animal origin is analyzed (Figure 6) because it indicates, alongside the share of dietary energy supply derived from cereals, roots and tubers (Figure 4), whether the diet is balanced between animal and vegetal food. The indicator includes the following groups: meat; offal; animal fats and products; milk and milk products; eggs, fish, seafood and sea products; and aquatic products. It has an upward trend, worldwide, since 1990 to 2011, from 24 grams per person per day to 31 grams per person per day.

Figure 6. Average supply of protein of animal origin (gram/caput/day).

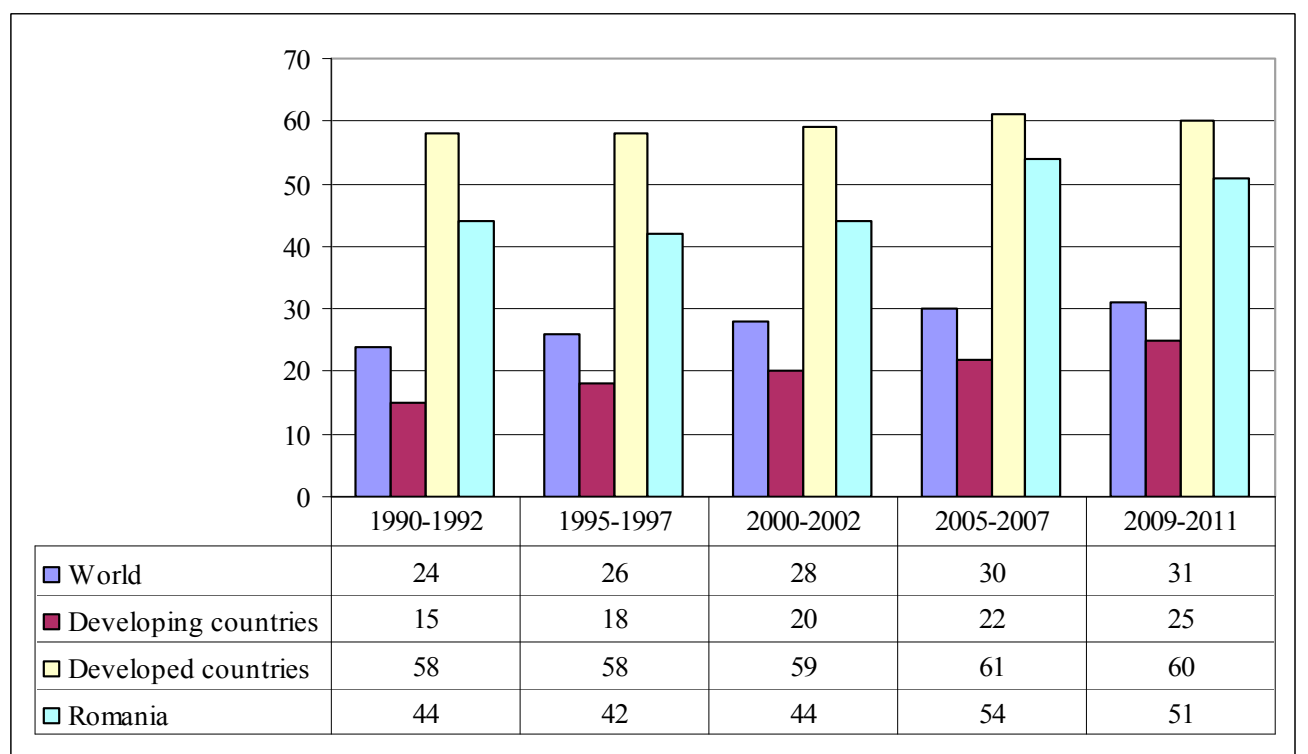

Source: Authors' calculation based on FAOSTAT data [24].

The cereal import dependency ratio is calculated by dividing the level of cereal import to cereal supply (calculated itself as cereal production plus cereal import minus cereal export). Low levels show 
the fact that a country can ensure food security from domestic agricultural production. In Romania, $12 \%$ of supply is provided by imports, while worldwide its level is $16 \%$. Romania is less dependent on cereal imports than other countries of the world. A negative aspect should be mentioned. The cereal import dependency ratio increased since 1990 to 2011, from $8.8 \%$ to $12 \%$ (Figure 7).

Figure 7. Cereal import dependency ratio (\%).

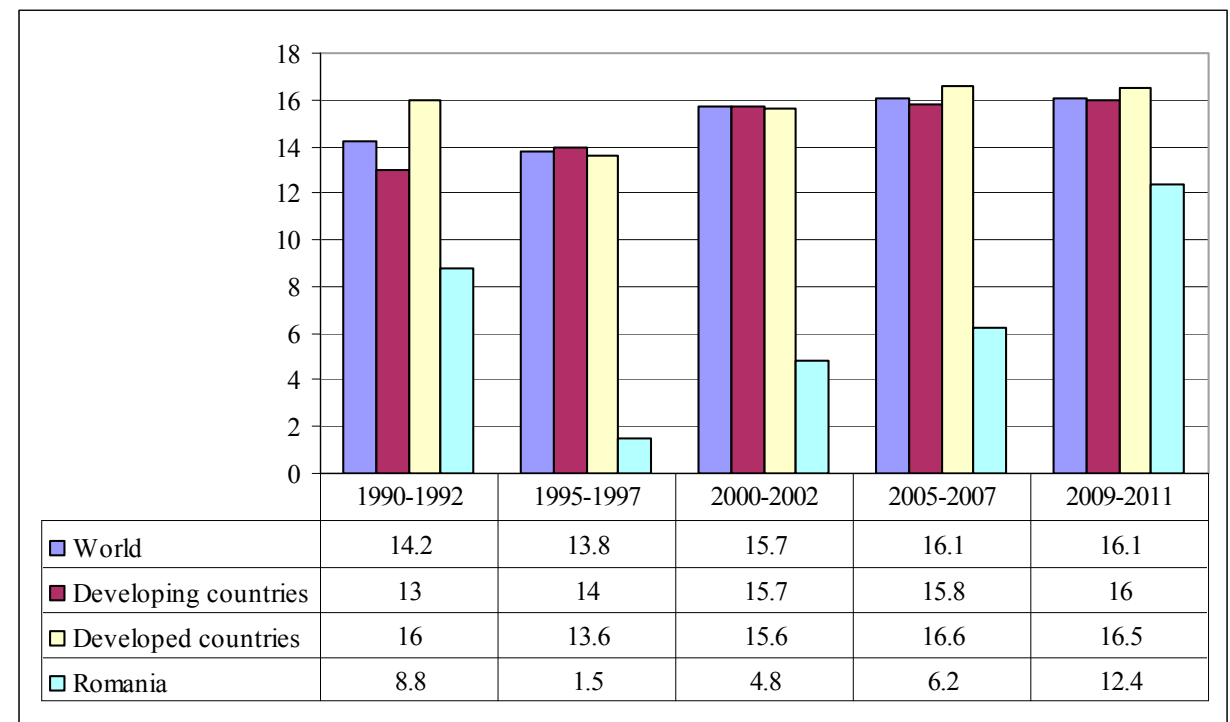

Source: Authors' calculation based on FAOSTAT data [24].

The average value of food production, expressed in international dollars (I\$) per person, is calculated by dividing the total value of annual food production, as estimated by FAO and published by FAOSTAT in International Dollars (I\$), to total population. It provides a cross-country comparable measure of the relative economic size of the food production sector in the country. As shown in Figure 8, the average value of food production is 378 I\$ per person in Romania, higher than its average world level of 303 I\$ per person, indicating a relatively important role of the agricultural sector in Romanian economy.

Figure 8. Average value of food production (I\$ per caput).

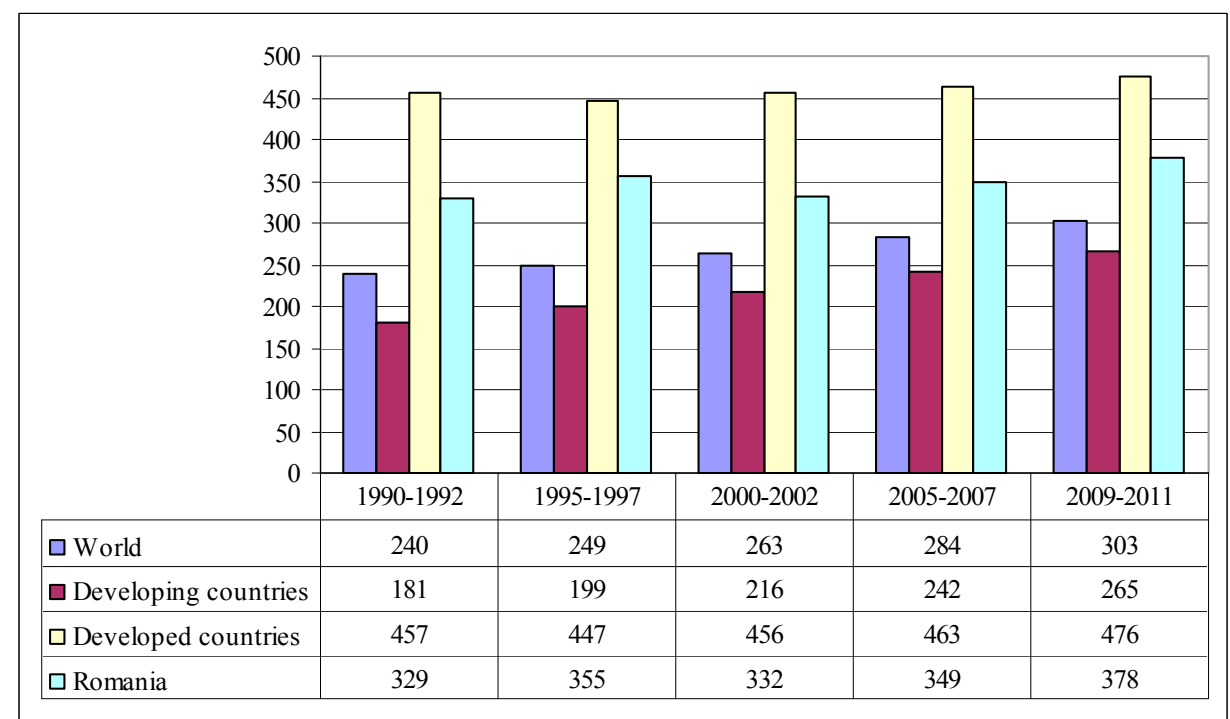

Source: Authors' calculation based on FAOSTAT data [24]. 


\section{Results and Discussions}

Analyzing the indicators of food security and findings of other research, some results can be revealed. They are presented from two points of view: quantitative and qualitative, as results from the nature of the indicator analysed in the experimental section.

As regards the quantitative approach, in Romania, dietary energy supply is above average dietary energy requirements. This demonstrates that food security is achieved, on average, considering the fact that the dietary energy supply is much higher than dietary energy requirements. Even more, dietary energy supply is $3363 \mathrm{kcal}$ per person per day, higher than its average of $2881 \mathrm{kcal}$ per person per day worldwide. The Department of Nutrition for Health and Development of World Health Organization (WHO), in collaboration with FAO, continually reviews new research and information from around the world on human nutrient requirements and recommended nutrient intakes (FAO [25]). Because daily average energy requirements are estimated depending on numerous factors: age, gendre, body weight, etc. it is difficult to indicate an average level recommended by the WHO, but still, $3363 \mathrm{kcal}$ per person per day shows that food security is achieved, in Romania, using a quantitative approach.

The dietary energy supply in Romania is higher than the average level of indicator "dietary energy requirements worldwide": $3363 \mathrm{kcal}$ per person per day compared to $2353 \mathrm{kcal} / \mathrm{person} /$ day (FAO database). FAO considers that the latter indicator (dietary energy requirements worldwide) is a proper normative reference for adequate nutrition in the population

Food security of a country is assured, essentially, from internal resources - agricultural output. Food self-sufficiency is an objective of agricultural policy of each country, because achieving it means high degrees of food independency. Cereals are the most important crop in Romania as regards area cultivated and the main product in food intake of consumers. This is the reason why the import dependency ratio is calculated for cereals. Romania has a low level of cereal import dependency ratio, $12 \%$, showing its potential for assuring food security mostly from domestic agricultural output.

As regards the qualitative approach, consumption of protein is higher than its level worldwide: 106 grams per day, compared to 79 grams per day. People in Romania have a balanced diet between vegetal and animal origin food, because the share of cereals, roots and tubers in total dietary energy supply is $45 \%$. Furthermore, dividing the average supply of protein of animal origin (data in Figure 6) to average protein supply (data in Figure 5), it results that, in Romania, half of protein intake is of animal origin, in developed countries $60 \%$ of protein intake is of animal origin, while worldwide its level is $39 \%$, and in developing countries 33\%. This strengthens, once more, the claim that people in Romania have a balanced diet between animal and vegetal origin food.

Since food security is achieved in a quantitative approach, the issue of quality also needs discussion. Thus, some changes in consumption pattern are considered, such as including organic food in diets. Organic farming emerged as a result of concerns about health and environment due to the intensification of agriculture technologies, and uses of chemicals, in both agriculture and the food processing industry.

The question is whether Romania has enough agricultural potential to sustain organic farming without compromising food security. The indicator "utilized agricultural area" must be analyzed to see if there are surfaces unused in the present and that can be utilized for organic farming. The total arable land in Romania, in 2011, was 9,352,300 hectares, of which the cultivated area was 8,081,600 hectares 
(Statistical yearbook of Romania [26] (pp. 421,432,433). The remaining 1,270,700 hectares can be cultivated with organic cereals and vegetables.

Furthermore, other reasons sustain the claim that Romania has potential for developing organic farming (BCG-Global Advisors [27] (p. 4), "high fertility of the farming land, low level of chemical pollution in the intensively cultivated lands, $30 \%$ of the arable land is uncultivated, which offers the opportunity of growing organic crops, increased area of natural pastures and forests, which meet the demands of the "ae" certification system, over 4 million subsistence farms can be rapidly and efficiently converted into micro organic farms".

\section{Conclusions}

Taking into account all of the considerations discussed above, a final answer to the research question is that, on average, food security is achieved in Romania, in terms of quantity. Analyzing the indicators of food security, Romania is placed above the average levels of indicators in the world in those regarding dietary energy supply adequacy, dietary energy supply, protein supply, supply of protein of animal origin, value of food production. Just $12 \%$ of cereals supply is ensured by imports, indicating a low dependency on imports for basic products such as cereals. Romanian people have a balanced diet between vegetal and animal origin food, because the share of cereals, roots and tubers in total dietary energy supply is $45 \%$ and half of protein intake is of animal origin.

However, since the analysed indicators express the average trend for a country, we may argue that food security is achieved, but on average, without considering the extremes. The indicators show a good level of food security in Romania, but this level can be achieved considering both people with very high dietary energy supply and very low dietary energy supply, meaning that these people do not have a proper access to food. This is a limit of the research, which results from the method of aggregation of the indicators calculated by FAO.

Food security is achieved as regards quantity, which opens discussions for quality. One qualitative aspect is introducing organic food in the diet, considering its benefits for health. Romania has agricultural potential to sustain such a change in the consumption pattern and the question is: to what extent can organic farming be developed without compromising food security in Romania? Further research can examine the answer to this question.

\section{Acknowledgments}

This work was co-financed from the European Social Fund through the Sectorial Operational Programme Human Resources Development 2007-2013, project number POSDRU/159/1.5/S/142115 "Performance and excellence in doctoral and postdoctoral research in the Romanian economics domain".

\section{Author Contributions}

The authors' contribution is equal. Nicolae Istudor designed the research and its reasoning and drawn conclusions, Raluca Andreea Ion made literature review and discussed data, Maria Sponte collected and analyzed data, Irina Elena Petrescu analyzed and discussed data and performed the paper editing. All authors read and approved the final manuscript. 


\section{Conflicts of Interest}

The authors declare no conflict of interest.

\section{References}

1. Food and Agriculture Organisation (FAO) website. Food security definition. Available online: http://www.fao.org/economic/ess/ess-fs/en/ (accessed on 18 September 2014).

2. Food and Agriculture Organisation (FAO); International Fund for Agricultural Development (IFAD); World Food Programme (WFP). The State of Food Insecurity in the World 2014. Strengthening the Enabling Environment for Food Security and Nutrition; FAO: Rome, Italy, 2014.

3. Food and Agriculture Organisation (FAO). Rome declaration on world food security and world food summit plan of action. In World Food Summit; FAO: Rome, Italy, 1996; pp. 13-17.

4. International Food Policy Research Institute (IFPRI). A 2020 Vision for Food, Agriculture, and the Environment: The Vision, Challenge, and Recommended Action; IFPRI: Washington, DC, USA, 1995.

5. Pinstrup-Andersen, P.; Pandya-Lorch, R. Food security and sustainable use of natural resources: A 2020 Vision. Ecol. Econ. 1998, 26, 1-10.

6. Cassman, K.G.; Harwood, R.R. The nature of agricultural systems: Food security and environmental balance. Food Policy 1995, 20, 439-454.

7. Parry, M.; Rosenzweig, C.; Iglesias, A.; Fischer, G.; Livermore, M. Climate change and world food security: A new assessment. Global Environ. Change 1999, 9, 51-67.

8. Hanjra, M.; Qureshi, E. Global water crisis and future food security in an era of climate change. Food Policy 2010, 35, 365-377.

9. Droogers, P. Adaptation to climate change to enhance food security and preserve environmental quality: Example for southern Sri Lanka. Agric. Water Manag. 2004, 66, 15-33.

10. Akenji, L.; Bengtsson, M. Making Sustainable Consumption and Production the Core of Sustainable Development Goals. Sustainability 2014, 6, 513-529.

11. Kang, Y.; Khan, S.; Ma, X. Climate change impacts on crop yield, crop water productivity and food security-A review. Prog. Nat. Sci. 2009, 19, 1665-1674.

12. Sage, C. The interconnected challenges for food security froma food regimes perspective: Energy, climate and malconsumption. J. Rural Stud. 2012, doi:10.1016/j.jrurstud.2012.02.005.

13. Devereux, S.; Edwards, J. Climate change and food security. IDS Bull. 2004, 35, 22-30.

14. Eakin, H. Institutional change, climate risk, and rural vulnerability: Cases from Central Mexico. World Dev. 2005, 33, 1923-1938.

15. Ericksen, P.J. Conceptualizing food systems for global environmental change research. Global Environ. Change 2008, 18, 234-245.

16. Timmer, P. The macro dimensions of food security: Economic growth, equitable distribution, and food price stability. Food Policy 2000, 25, 283-295.

17. Constance, D.H. Sustainable Agriculture in the United States: A Critical Examination of a Contested Process. Sustainability 2010, 2, 48-72. 
18. Botezatu, M.; Andrei, J. Implications of the environmental factors on the economic efficiency of capital investments. A Romanian perspective in terms of a sustainable economy. J. Environ. Prot. Ecol. 2012, 13, 382-391.

19. Ion, R.A.; Popescu, G.C. Food Security: Changes and Trends on World Agricultural Markets. In Proceedings of Competitiveness of Agro-food and Environmental Economy, Bucharest, Romania, 7-8 November 2013.

20. Done, I.; Chivu, L.; Andrei, J.; Matei, M. Using labor force and green investments in valuing the Romanian agriculture potential. J. Food Agric. Environ. 2012, 10, 737-741.

21. Bazga, B. Prospects for food security in Romania. Proced. Econ. Financ. 2012, 3, 1262-1267.

22. Economist Intelligence Unit. An Assessment of Food Affordability, Availability and Quality. In Global Food Security Index 2012; Economist Intelligence Unit: London, UK, 2012.

23. Economist Intelligence Unit. An Annual Measure of the State of Global Food Security. In Global Food Security Index 2014; Economist Intelligence Unit: London, UK, 2014.

24. Food and Agriculture Organisation (FAO). Available online: http://faostat3.fao.org/home/E (accessed on 8 September 2014).

25. Food and Agriculture Organisation (FAO). Human energy requirements. Available online: http://www.fao.org/docrep/007/y5686e/y5686e00.htm (accessed on 19 September 2014).

26. Statistical Yearbook of Romania. Available online: http://www.insse.ro/cms/ro/content/anuarulstatistic-2012 (accessed on 8 August 2014).

27. BCG-Global Advisors; Bio-Romania Association; The University of Bucharest; Romanian Organic Sector. Business Insight Booklet; The University of Bucharest: Bucharest, Romania, 2012.

(C) 2014 by the authors; licensee MDPI, Basel, Switzerland. This article is an open access article distributed under the terms and conditions of the Creative Commons Attribution license (http://creativecommons.org/licenses/by/4.0/). 